University of Nebraska - Lincoln

DigitalCommons@University of Nebraska - Lincoln

1972

\title{
Late Quaternary Eustatic Sea-Level Changes Along The Malibu Coast, Los Angeles County, California
}

Peter W. Birkeland

University of Colorado at Boulder

Follow this and additional works at: https://digitalcommons.unl.edu/usgsstaffpub

Part of the Earth Sciences Commons

Birkeland, Peter W., "Late Quaternary Eustatic Sea-Level Changes Along The Malibu Coast, Los Angeles County, California" (1972). USGS Staff -- Published Research. 492.

https://digitalcommons.unl.edu/usgsstaffpub/492

This Article is brought to you for free and open access by the US Geological Survey at DigitalCommons@University of Nebraska - Lincoln. It has been accepted for inclusion in USGS Staff -- Published Research by an authorized administrator of DigitalCommons@University of Nebraska - Lincoln. 


\title{
LATE QUATERNARY EUSTATIC SEA-LEVEL CHANGES ALONG THE MALIBU COAST, LOS ANGELES COUNTY, CALIFORNIA ${ }^{1,2}$
}

\author{
PETER W. BIRKELAND \\ Department of Geological Sciences, University of Colorado, Boulder, Colorado 80302; \\ and U.S. Geological Survey, Denver, Colorado 80225
}

\begin{abstract}
Late Quaternary relative sea-level changes along the Malibu coast can be deciphered by study of geomorphic features and marine and associated stream deposits. Evidence for such changes includes $(a)$ stream downcutting in large valleys during low stands of sea level, $(b)$ stream aggradation in the same valleys during high stands of sea level, and $(c)$ marine shoreline angles whose altitudes coincide with the tops of valley-fill stream deposits. This evidence, and open-system uranium-series dates for shells from the Corral and Dume terrace deposits, provide a time scale for certain sea-level changes. Evidence from other coasts of the United States suggests that sea level was close to its present position about 30,000 years ago. Such a post-Dume, preHolocene relatively high stand of sea level has not been recognized in marine deposits along the Malibu coast. There is evidence, however, for stream aggradation at possibly 30,000 years B.P. Sea-level position at that time cannot be determined, but considerations of tectonic rate of uplift suggest that it was no higher than about -30-foot altitude. Most of the relative sea-level changes identified here are probably due to eustatic variations in sea level. Tectonic movements complicate the interpretation of the stratigraphic and geomorphic record; however, because movements seem to have been consistently upward, relative rises of sea level are interpreted as eustatic and relative falls as partly eustatic. Eustatic origin is also suggested by the similarities in ages of sea-level fluctuations between the Malibu coast and the coasts of Alaska, Barbados, Mallorca, and New Guinea.
\end{abstract}

\section{INTRODUCTION}

Marine terraces along the California coast have drawn the attention of many geologists over the years. Despite this, little is known of their relation to eustatic variations in sea level, and little progress has been made in methods used for terrace correlation. Data presented in recent reviews by King (1965) and by Wahrhaftig and Birman (1965) indicate that the altitude of either terrace or shoreline angle is of little use in long-range correlation along the coast, mainly because of differing Quaternary tectonic movements.

The purposes here are (1) to present stratigraphic data for the Malibu coast which indicate that some marine terrace deposits relate to eustatic changes in sea level, (2) to point out the relation of these deposits to previously published uranium-

${ }^{1}$ Manuscript received August 11, 1971; revised February 8, 1972.

${ }^{2}$ Publication authorized by the Director, U.S. Geological Survey.

[Journal of Geology, 1972, Vol. 80, p. 432-448]

(c) 1972. The University of Chicago. All rights reserved. series shell dates, and then (3) to compare the resulting sea-level variation curve with the curves from coasts in other parts of the world. Data on eustatic sea-level variation must come from detailed study of both marine and nonmarine deposits and of coastal tectonics. Stream deposits whose tops coincide in altitude with marine shoreline angles can, by their thickness, be used to help differentiate marine terrace deposits laid down during a continuously falling sea level, relative to land, from those laid down during a fluctuating sea level. This kind of streamdeposit record is best seen in large valleys that head in the interior of the Santa Monica Mountains. Four relatively high stands of sea level during the last 150,000 years are recognized. Each high stand is separated from the others by relatively low stands of sea level. That the swings in sea level are mainly of eustatic origin is suggested by analysis of tectonic movements, as deduced from shoreline-angle altitudes and assumed altitudes of interglacial sea levels and by similarity with dated sea-level fluctuations for coasts in other parts of the world.

Location and geologic setting.-The area 
of study is the Malibu coast along the south side of the Santa Monica Mountains (fig. 1). Quaternary deposits between Bass Rock and Topanga Canyon (fig. 6) were mapped at a scale of $1: 20,000$. In addition, reconnaissance studies were made westward to the Oxnard Plain along the coast, eastward to the city of Santa Monica, and at the $\mathrm{Pa}$ los Verdes Hills.

The most recent summaries of the geology of the central Santa Monica Mountains are by Yerkes and Wentworth (1965) and Campbell and others (1966). Sedimentary and volcanic rocks of Cretaceous to Miocene age make up most of the bedrock along the coast. Movement on some faults, which displace many of the bedrock units, has continued into the late Quaternary, as evidenced by local displacement of marine terrace deposits.

Previous work.-Davis (1933) has described the geomorphic relations and Quaternary stratigraphy of the Malibu coast, and many of his findings have been verified in this study. His main conclusions were that the marine terraces were cut during in- terglacial high stands of sea level, that sea level was low between the times of formation of successive marine terraces, and that the times of low sea-level position correlate with times of glaciations elsewhere. He presented little field evidence, however, to demonstrate transgression and regression. He named the two prominent emergent marine terraces Dume and Malibu (the older). He also recognized tilting of the Dume terrace. Although he correlated terrace deposits eastward along the coast to Santa Monica with the Dume terrace, it now seems that some of these deposits could be pre-Dume in age. In the present study an effort was made to correlate the Malibu coast terrace deposits with those near Santa Monica, but no satisfactory basis for correlation was obtained.

The only other detailed study of the Quaternary deposits in this area is the work of Yerkes and Wentworth (1965). They recognized a marine terrace intermediate in position between the Dume and Malibu terraces, located shoreline-angle positions, described upper Quaternary subaerial de-

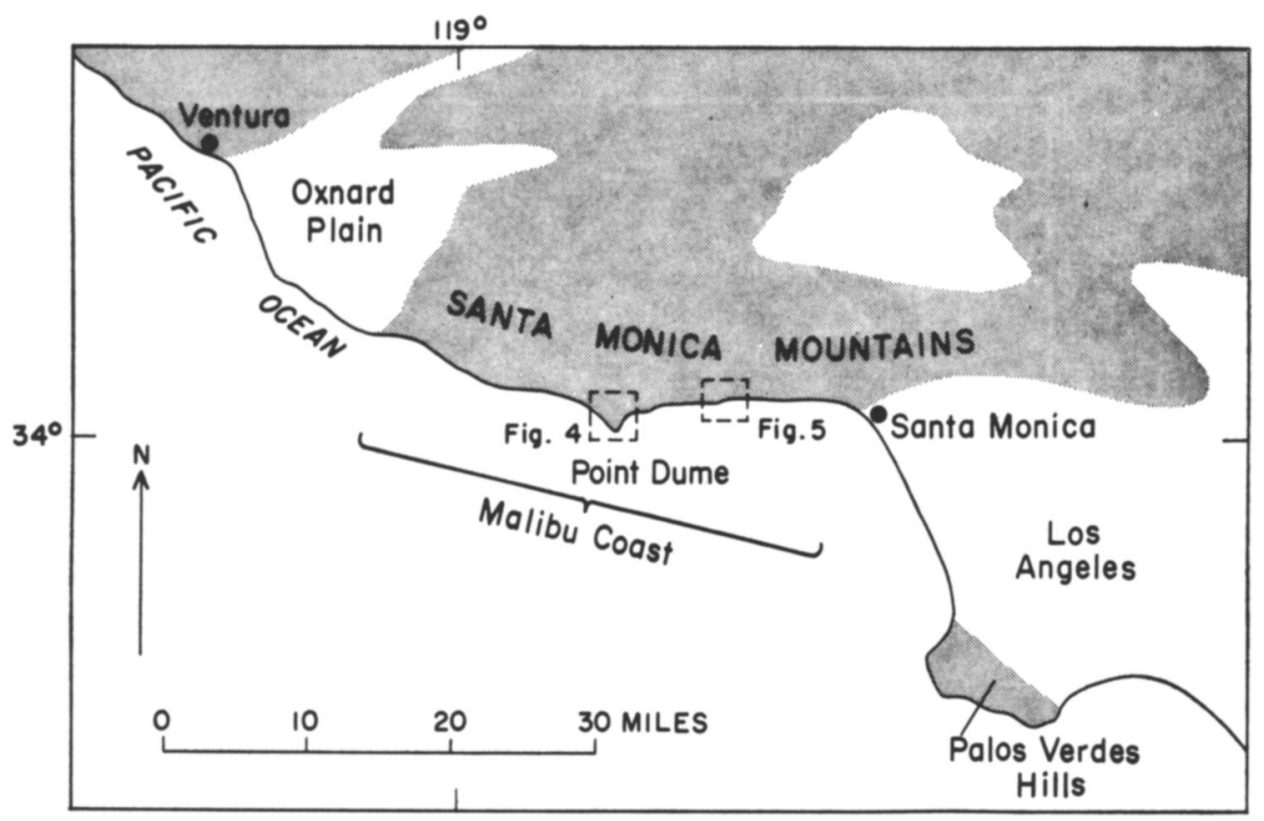

Fig. 1.-Location map of area. Mountainous areas are shaded. 
posits, soils, and deformation in considerable detail; and provided the shells for the initial uranium-series dates on the marine terrace deposits. More recently, Szabo and Rosholt (1969) refined the dating methods and reported all age determinations to date. Detailed geologic maps of the coastal area (1:12,000 scale) have been released to open file by the U.S. Geological Survey (Yerkes and others 1964, 1971; Campbell and others 1970).

\section{SEDIMENTARY DEPOSITS}

Two kinds of sedimentary depositsbeach and stream-are essential for reconstruction of the Quaternary history, mainly because their interrelations and altitudes provide control points for the eustatic sealevel variation curve. Gravel roundness and sorting of $<2-\mathrm{mm}$ material are the main criteria used to distinguish one type of deposit from the other (figs. 2, 3).

Beach deposits, consisting predominantly of well-sorted sand, rest on marine-abrasion platforms and range in thickness from several inches to 21 feet. Gravel, where present, is generally found at the base of the deposits. The clasts, most of which are pebble size, are subrounded to rounded, and their surfaces are fairly smooth and display little microrelief. Some beach deposits are unoxi-

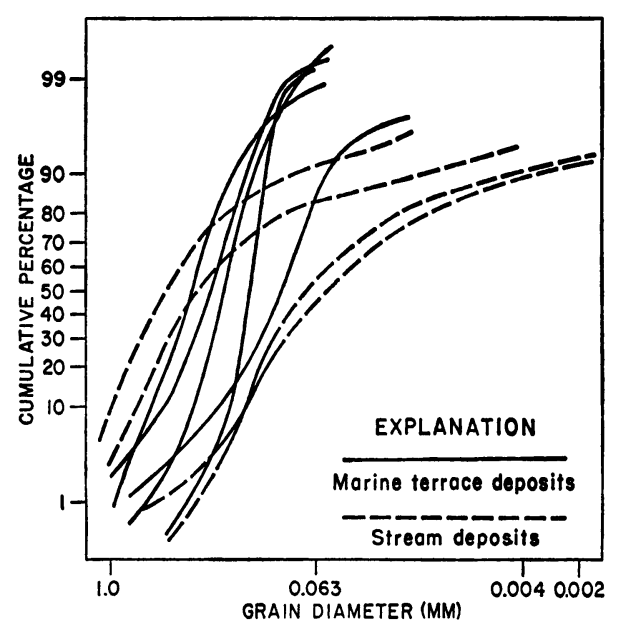

FIg. 2.-Cumulative curves for $<2$-mm fraction of marine terrace and stream deposits.
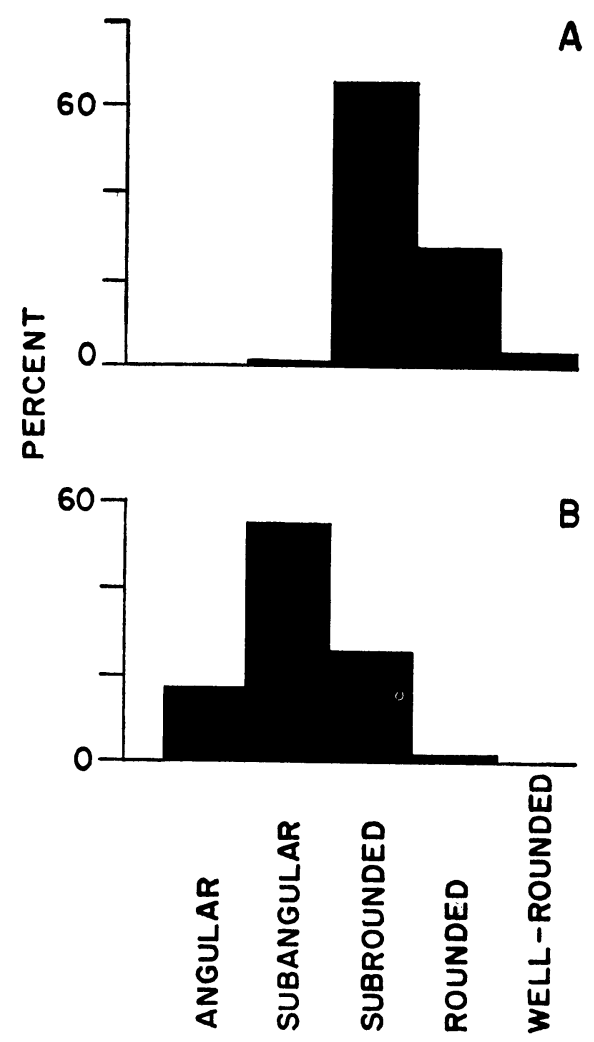

FIg. 3.-Roundness of 1-3-inch clasts in marine $(A)$ and stream $(B)$ gravel. Determined visually using chart of Powers (1953).

dized, or only slightly oxidized, and are not indurated, whereas other deposits are brown (7.5 YR 5/4) and are moderately indurated; there are no consistent trends with age, however. (Color notations are from the Munsell Soil Color Charts, 1954 edition.)

Stream deposits, consisting typically of interbedded sand and gravel, are common in most valleys and vary in thickness from veneers several feet thick to valley fills more than 100 feet thick. The sand fraction is moderately to poorly sorted, and the gravel clasts generally are subangular to subrounded with slightly irregular microrelief. Gravel ranges in size from pebbles to 5-foot boulders.

Alluvial-fan deposits occur at the foot of most steep slopes, and in many places they rest on the beach and stream deposits. Thicknesses vary from several feet to more 
than 100 feet. Characteristic features include poor sorting of both matrix and gravel sizes, crude layering parallel to fan surfaces, the common occurrence of clay-rich layers, and only slight rounding of gravel clasts.

\section{QUATERNARY STRATIGRAPHY}

The stratigraphic nomenclature is modified from that of Davis (1933), who first described the Malibu and Dume terraces. Yerkes and Wentworth (1965) named the intermediate terrace near Corral Canyon terrace $\mathrm{C}$; it is here designated the Corral terrace.

The relative ages and correlations of Quaternary deposits along the Malibu coast are primarily based on continuity and altitude. In addition, stratigraphic relations suggest that for any part of the Malibu coast the marine and stream deposits are progressively older with increasing altitude. Other correlation methods that were tried included analysis of soils and heavy-mineral etching. Soils proved to be of little use in correlation, because in most places alluvialfan deposits covered the marine sediments before much soil formation could take place. Bradley $(1957,1965)$ has demonstrated that the degree of etching of heavy minerals and selective loss of heavy minerals during weathering were effective tools for correlating marine deposits in the Santa Cruz, California, area. A similar approach attempted in this study was not successful. Slightly altered marine sand, collected several feet above the bedrock platform from many of the terrace deposits, was analyzed. In most samples, pyroxene grains are highly etched, whereas hornblende grains are unetched or only slightly etched. This relation occurs in Quaternary marine terrace deposits of all ages along the Malibu coast, including those near Santa Monica.

Terrace continuity varies along the coast. The Dume terrace is nearly continuous from Little Sycamore Canyon to Malibu Creek, whereas the Corral terrace, though recognized near Point Dume, is continuous only from Corral Canyon to Malibu Creek. The largest expanses of Malibu terrace deposits are near Point Dume; elsewhere, deposits of this age occur only as isolated remnants. Because all terrace deposits are discontinuous east of Malibu Creek, correlation there is difficult and based only on altitude, position in terrace sequence, and on the assumption that the tectonic style west of Malibu Creek-uptilting to the east-continues east of Malibu Creek.

Pre-Malibu deposits.-Marine sands and stream deposits at altitudes higher than the nearby Malibu terrace are considered to be of pre-Malibu age. They are most common north and west of Point Dume (figs. 4, 5, 6). Because these deposits are at various altitudes, several ages probably are included. The marine deposits cannot be related to a eustatic high stand of sea level because none of the deposits can be correlated with a nonmarine valley fill. A 100 -foot-thick stream deposit whose top is about 350 feet in alti. tude crops out along the valley side just west of Malibu Creek (fig. 5). Although a deposit in that position and of that thickness is suggestive of stream aggradation during a rise in sea level, no marine deposits with which it might correlate are nearby.

Malibu marine and stream deposits.Malibu marine terrace deposits are related to a shoreline angle that is between 200 and 250 feet in altitude near Point Dume (fig. 6). The best exposures are in the highway cut north of Point Dume (Davis 1933, p. 1064), where 9 feet of nonmarine alluvium rests on 10 feet of marine sand and gravel, which in turn rests on the bedrock platform (loc. $M$, fig. 4). A 125 -foot-thick stream deposit along Zuma Creek has a top at an altitude close to that of the nearby Malibu shoreline angle (fig. 4). This suggests that Zuma Creek was aggrading just prior to formation of the Malibu terrace, which in turn suggests that the Malibu terrace was formed during a transgression.

Corral marine and stream deposits.-Corral marine terrace deposits are related to a shoreline angle that is between about 150 and 176 feet in altitude between Point Dume and Malibu Creek. The best exposure in that area is just west of the mouth 


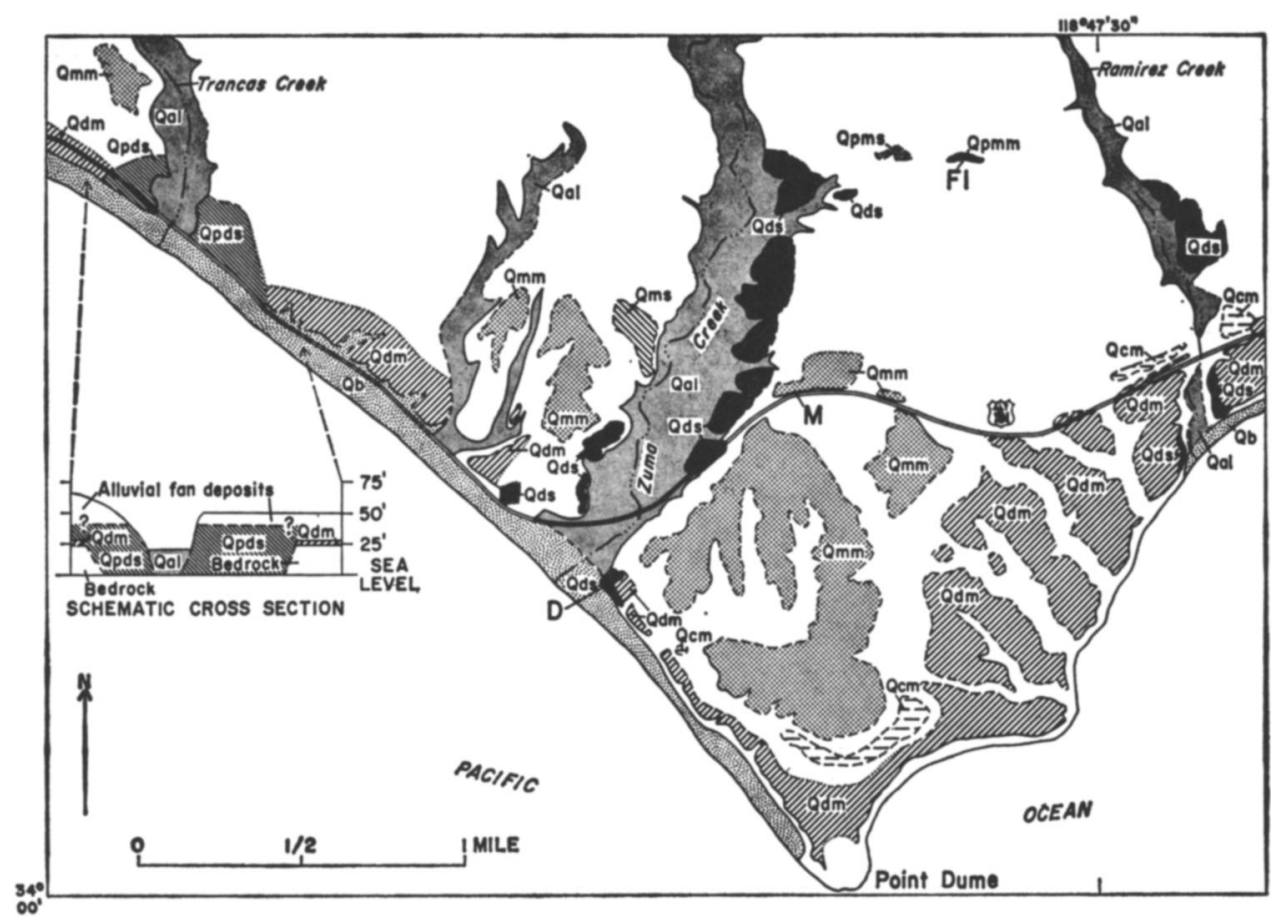

FIg. 4.-Quaternary geology of the Malibu Coast near Point Dume

of Corral Canyon (loc. $C$, fig. 5), where as much as 20 feet of marine deposits rest on the marine abrasion platform (Yerkes and Wentworth 1965, p. 36-40, 157-158). Yerkes and Wentworth (1965) also described other occurrences of Corral marine terrace deposits that were exposed in artificial trenches just east of Corral Canyon.

Valley cutting and subsequent stream aggradation preceded formation of the Corral marine terrace. Deposits of stream gravel, as much as 125 feet thick, crop out in several places near the mouth of Malibu Creek. They are though to be of Corral age because their tops are close in altitude to that of the nearby Corral shoreline angle. In addition, stream deposits more than 150 feet thick crop out along the east side of the mouth of Las Flores Canyon and contain in their upper part a sand unit of probable marine origin. This sand lies just south of, and close to the altitude of, the 175-foot abrasion platform of probable Corral age (fig.
6). Hence, data from the stream deposits indicate that a major regression occurred between the formation of the Malibu and the Corral marine terraces.

Three open-system uranium-series shell dates have been obtained for the Corral terrace deposits (Szabo and Rosholt 1969). They range from $115,000 \pm 15,000$ years to $154,000 \pm 30,000$ years, and average $131,000 \pm 15,000$ years.

Dume marine and stream deposits.-Dume marine terrace deposits are related to a shoreline angle that varies from less than $\mathbf{5 0}$ feet in altitude at the western end of the study area to 130 feet in the eastern part (fig. 6). The best exposures are in the sea cliff just east of the mouth of Zuma Creek (loc. $D$, fig. 4 ), where the relations of marine and nonmarine deposits can be explained in terms of eustatic sea-level rise. At that locality, 18 feet of marine sand and gravel rest conformably on 59 feet of stream deposits laid down by Zuma Creek. The base 
EXPLANATION
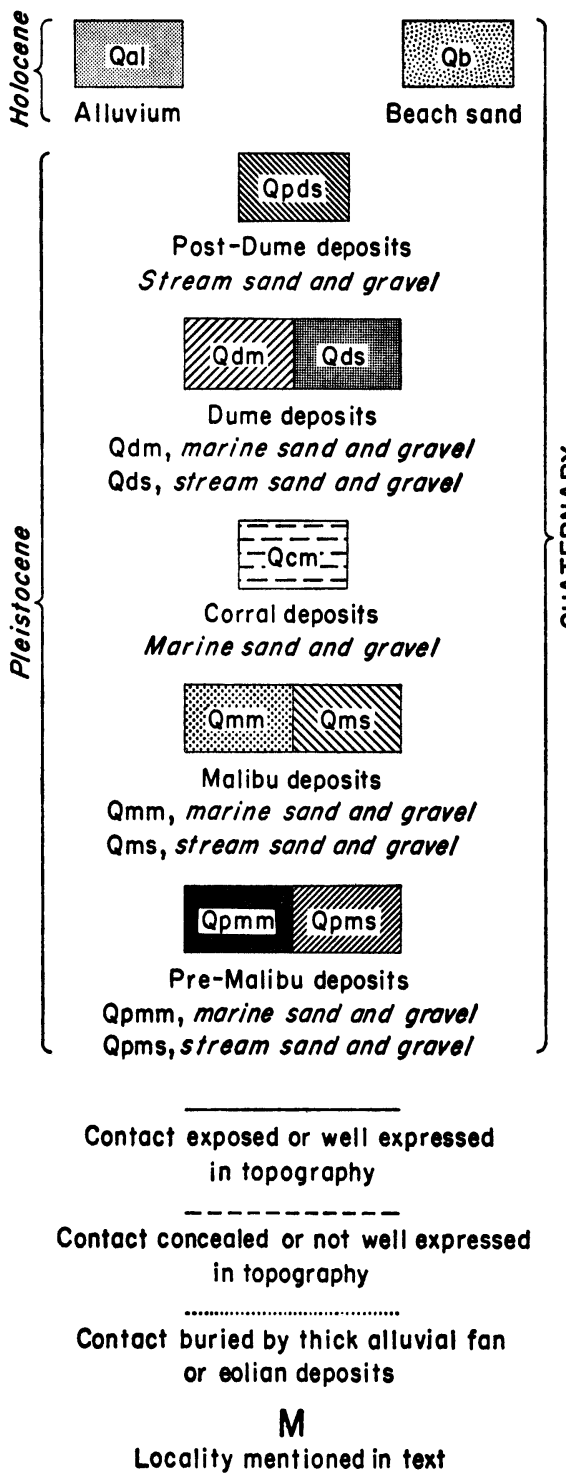

of the stream deposits is not exposed and extends below present beach level. Upstream along Zuma Creek are stream-fill terrace deposits. The tops of the terrace remnants grade downvalley to the altitude of the Dume shoreline angle, thus indicating that the stream terrace deposits and the marine and nonmarine deposits in the sea cliff all relate to the same transgression. The record is interpreted to mean that while sea level was rising Zuma Creek aggraded, and that only near the end of the period of transgression did the sea get close enough to the present shore to deposit marine sand and gravel on previously deposited stream alluvium.

Some deposits mapped as stream deposits may have been deposited in an estuarine environment. After this study was completed, fossils were collected by C. M. Wentworth at locality $D$ (fig. 4) from a position about 8 feet below the top of the stream deposit. J. E. Hazel (written communication, 1970) has identified them as Ostracoda, with Cyprideis beaconensis being abundant and Cypridopsis vidua scarce. $\mathrm{He}$ interprets this assemblage as indicating deposition probably in an estuary that had a salinity in the oligohaline range.

Several valleys east of Point Dume also contain stream deposits related to the Dume terrace, either as fill- or strath-terrace deposits (figs. 4, 5). Age assignment is based either on position directly beneath Dume marine deposits or because the gradient on their tops projects close to the position of the Dume shoreline angle.

These relations of marine and nonmarine deposits suggest that the Dume and Corral marine terrace deposits were separated by a period of major marine regression and valley deepening. A regression of similar magnitude followed formation of the Dume terrace.

Seven open-system uranium-series shell dates have been obtained for the Dume marine deposits (Szabo and Rosholt 1969). They range from $95,000 \pm 25,000$ years to $112,000 \pm 15,000$ years, and average $104,000 \pm 5,000$ years.

Post-Dume deposits.-Stream deposits in several major valleys form terraces that either are below or their tops project to an altitude below that of the Dume shoreline angle (figs. 4, 5). A pre-Holocene age is suggested by their position above recognized Holocene alluvium and by their brown color (7.5YR); in contrast, Holocene alluvium generally is yellow brown (10YR 3/4- 


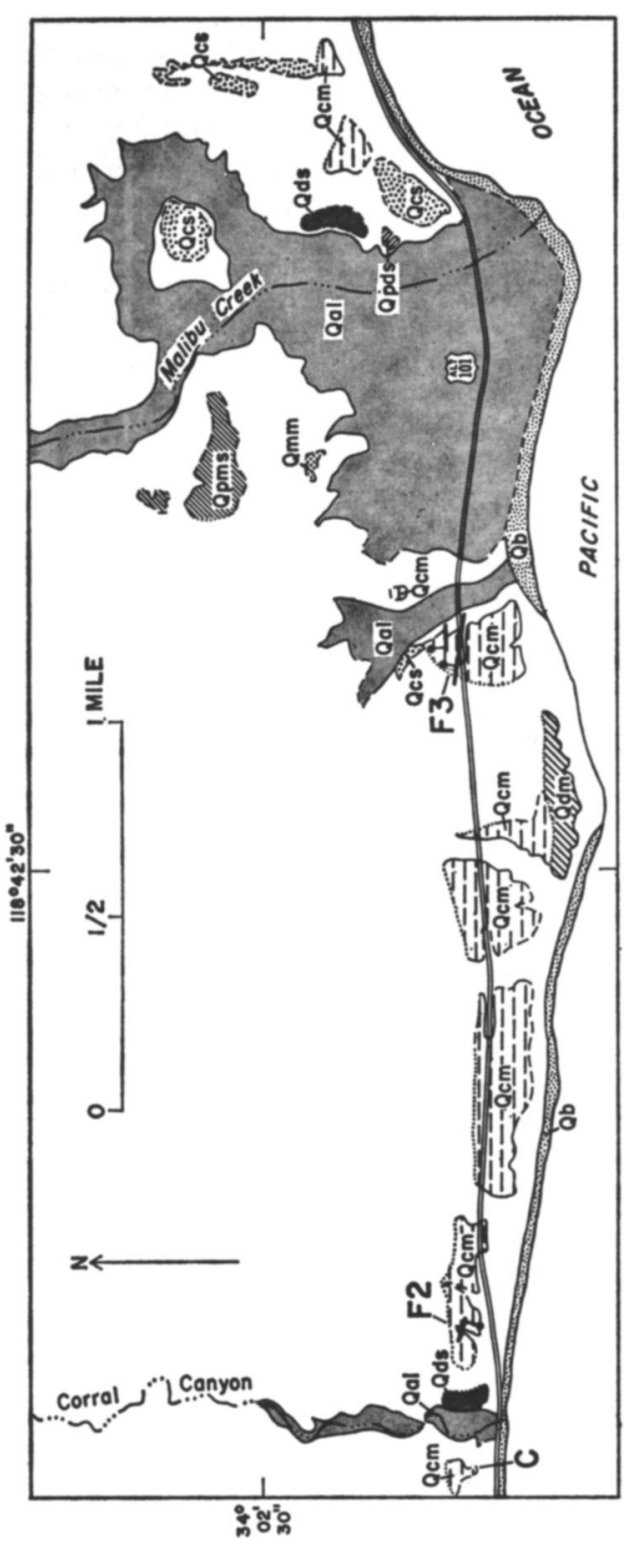

Fig. 5.-Quaternary geology of the Malibu Coast near the mouth of Malibu Creek.

10YR 5/4). This browner color seems to be partly age dependent.

Alluvium.-Stream deposits along most valley bottoms are judged to be of Holocene age because either they are graded to present sea level or they occur as low terraces whose tops are no more than 25 feet above

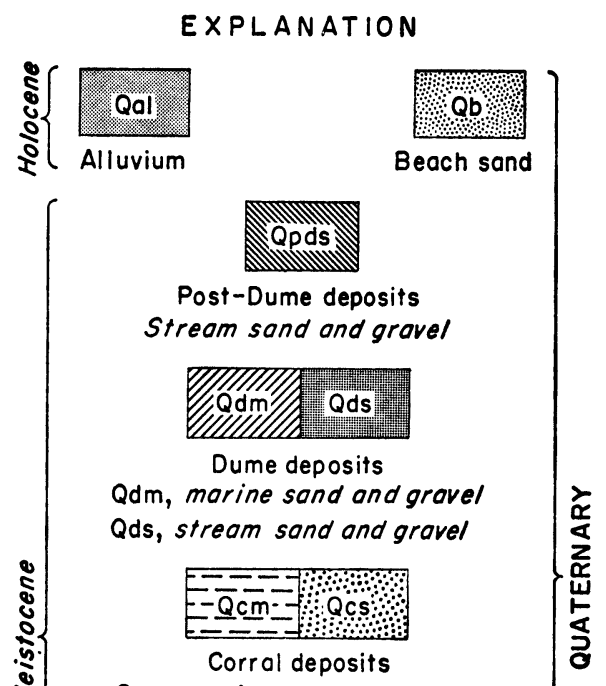

Qcm, marine sand and gravel

Qcs, stream sand and gravel

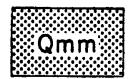

Malibu deposits

Marine sand and gravel

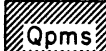

Qpms

Pre-Malibu deposits

Stream sand and gravel

Contact exposed or well expressed

in topography

$----------$

Contact concealed or not well expressed in topography

Contact buried by thick alluvial fan or eolian deposits

Fault with late Quaternary displacement Bar and ball on downthrown side

C

Locality mentioned in text

the highest nearby beach sand. Such low terraces could have been formed during stream incision accompanying Holocene seacliff retreat.

Table 1 gives the time scale for sea-level changes in the terrace deposits. 
TABLE 1

Time SCAle for Sea-Level Changes

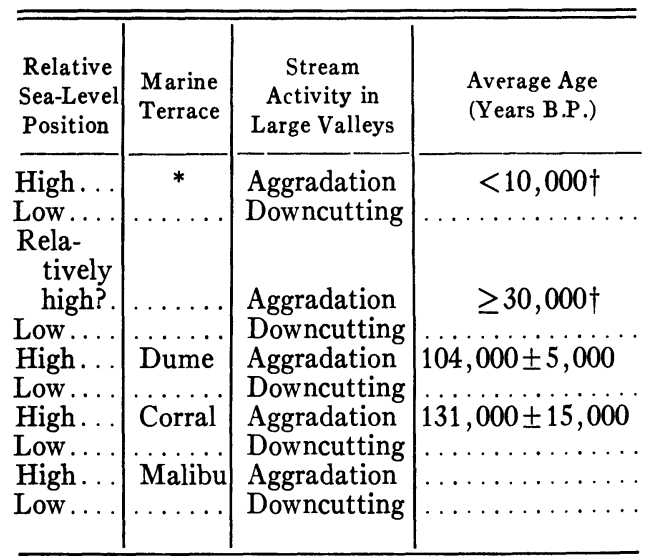

* Being cut at present.

$\dagger$ No absolute dates; ages are estimated and based on correlation with events elsewhere.

The thickness of Holocene alluvium in the major stream valleys indicates deposition of the alluvium during a major transgression, the Monic transgression of Davis (1933). Few water wells drilled into this alluvium reach bedrock; those that do may not be located at the deepest part of the valley fill. Davis (1933, p. 1078) reported a thickness of 76 feet for the alluvium at Sycamore Creek, and the records of the Marblehead Land Company (oral communication, 1968) indicate minimum thicknesses of 89 feet for the alluvium at Zuma Creek and 105 feet for the alluvium at Malibu Creek.

\section{LATE QUATERNARY TECTONIC MOVEMENTS}

The amount of deformation of the marine terrace deposits is indicated by the variation in altitude of abrasion platforms and shoreline angles along the coast (fig. 6). Regional tilting arching, and faulting have all contributed to this deformation.

The Malibu coast has been tilted in post-Dume time, the overall relative movement being up in the east and down in the west (Davis 1933, p. 1051-1052). The easternmost measured altitude on the Dume shoreline angle is 130 feet just west of Topanga Canyon (fig. 6). Westward, the Dume shoreline angle decreases only slightly to between 109 and 120 feet just west of Point Dume, and then decreases more rapidly farther west until it lies between 25 and 40 feet in altitude just east of Bass Rock. West of Bass Rock in the Santa Monica Mountains neither Davis (1933, p. 1069-1070) nor I located any Dume deposits. At the west end of the Santa Monica Mountains young alluvium makes up the Oxnard Plain. These relations suggest that the Dume shoreline angle is close to or below present sea level at the western edge of the Santa Monica Mountains (Davis 1933, p. 1051-1052).

Large-scale tilting of pre-Dume deposits is less well defined, because the deposits are less extensive and more poorly preserved and because correlation east of Malibu Creek is difficult. The Corral shoreline angle is between 154 and 175 feet in altitude at Point Dume and rises eastward to 190 feet at Las Flores Canyon. Altitudinal control on the Malibu shoreline angle indicates that it rises from between 211 and 236 feet at Point Dume to 318 feet just west of Topanga Canyon. In that section of the coast for which there is altitudinal control on all three terraces, the data on the Dume and Corral terraces can be interpreted as indicating that the terraces are nearly parallel, and hence most of the differential uplift is post-Dume. In contrast, the Malibu terrace appears to rise more rapidly eastward than the Corral terrace, indicating that some of the differential movement is pre-Corral.

The relatively high altitude above present sea level of many of the marine deposits indicates that much of the Malibu coast has been rising in late Quaternary time. Guilcher (1969, p. 73) recently reviewed the data on the positions of interglacial sea levels and concluded that the levels may have been no more than a few meters above present sea level. If this is correct, then most of the marine terrace deposits studied here must have been uplifted. This contention is supported by the fact that marine deposits in the study area are as high or higher in altitude than marine deposits of nearly equivalent ages on other coasts (fig. 9). That this upward movement has 
品

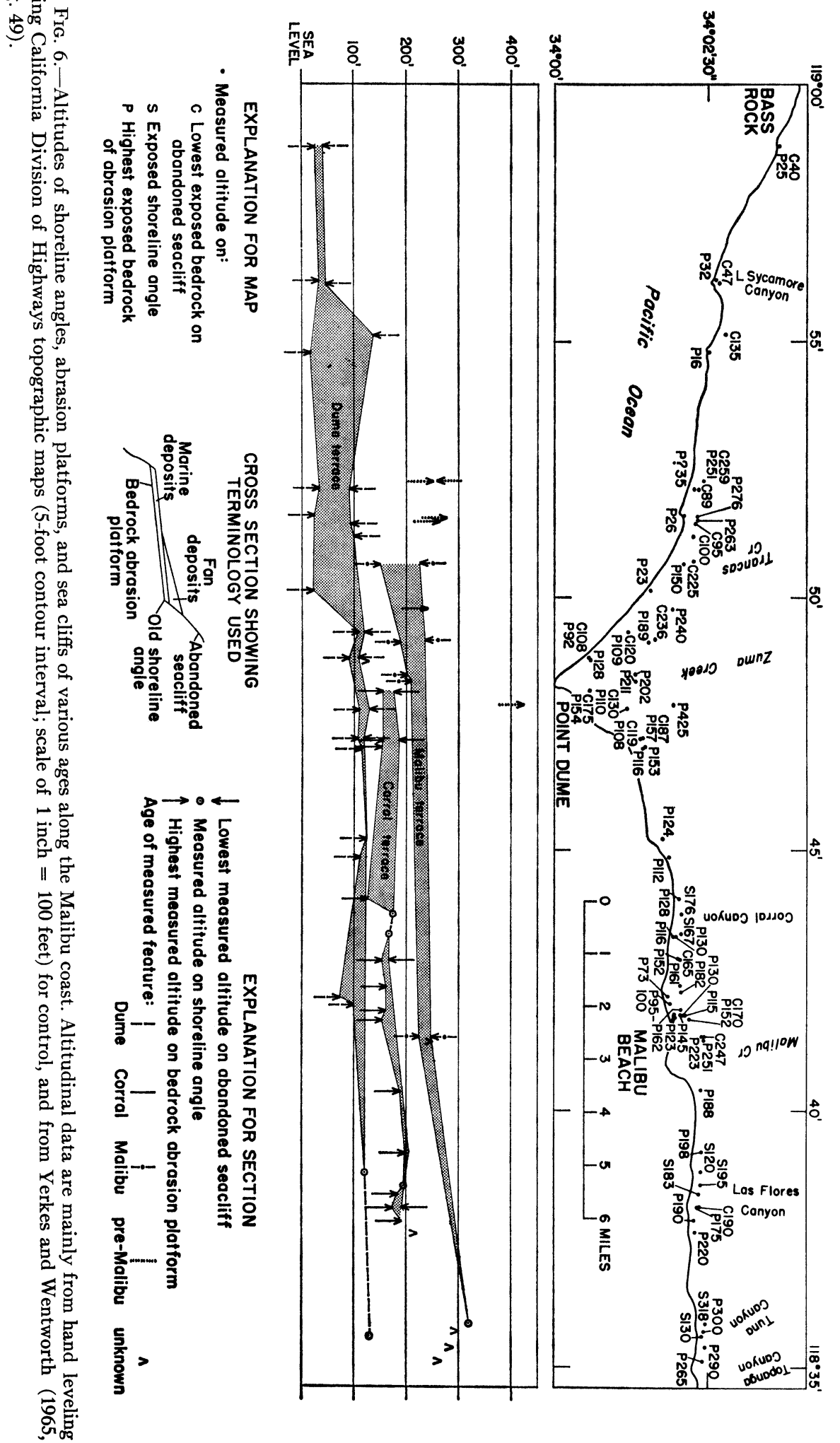


been going on for a long time is indicated by the presence of older deposits at progressively higher altitudes.

Some rough rates of late Quaternary uplift can be calculated from the above data and the radiometric ages of Szabo and Rosholt (1969) for the Dume and Corral terraces. These rates amount to $1-1.2$ feet per 1,000 years near Point Dume to $1.2-1.5$ feet per 1,000 years between Las Flores and Tuna Canyons.

Pleistocene deposits have been displaced along faults in several places. Pre-Malibu nonmarine deposits are vertically separated a minimum of 12 feet at locality $F 1$ (fig. 4) north of Point Dume (Yerkes and Wentworth 1965, p. 151). Deformation of Cor. ral marine deposits just east of Corral Canyon (loc. F2, fig. 5) is complex and only ob- served in good exposures (Yerkes and Wentworth 1965, p. 159-174); maximum vertical separation, perhaps the result of tectonic movement, is 17 feet along a north-dipping thrust fault. Corral marine deposits are also faulted at locality $F 3$ (fig. 5), where the marine abrasion platform and overlying marine deposits are displaced along two faults, both down on the north side and with total vertical separation nearly 47 feet.

\section{SEA-LEVEL VARIATION AND ITS ORIGIN}

The stratigraphic and altitudinal relations of both marine and nonmarine deposits can be used to construct a curve for relative changes in sea level, as discussed by Upson (1949) and Alexander (1953). The effects of the Holocene transgression serve as a model (fig. 7). Sea level was low during
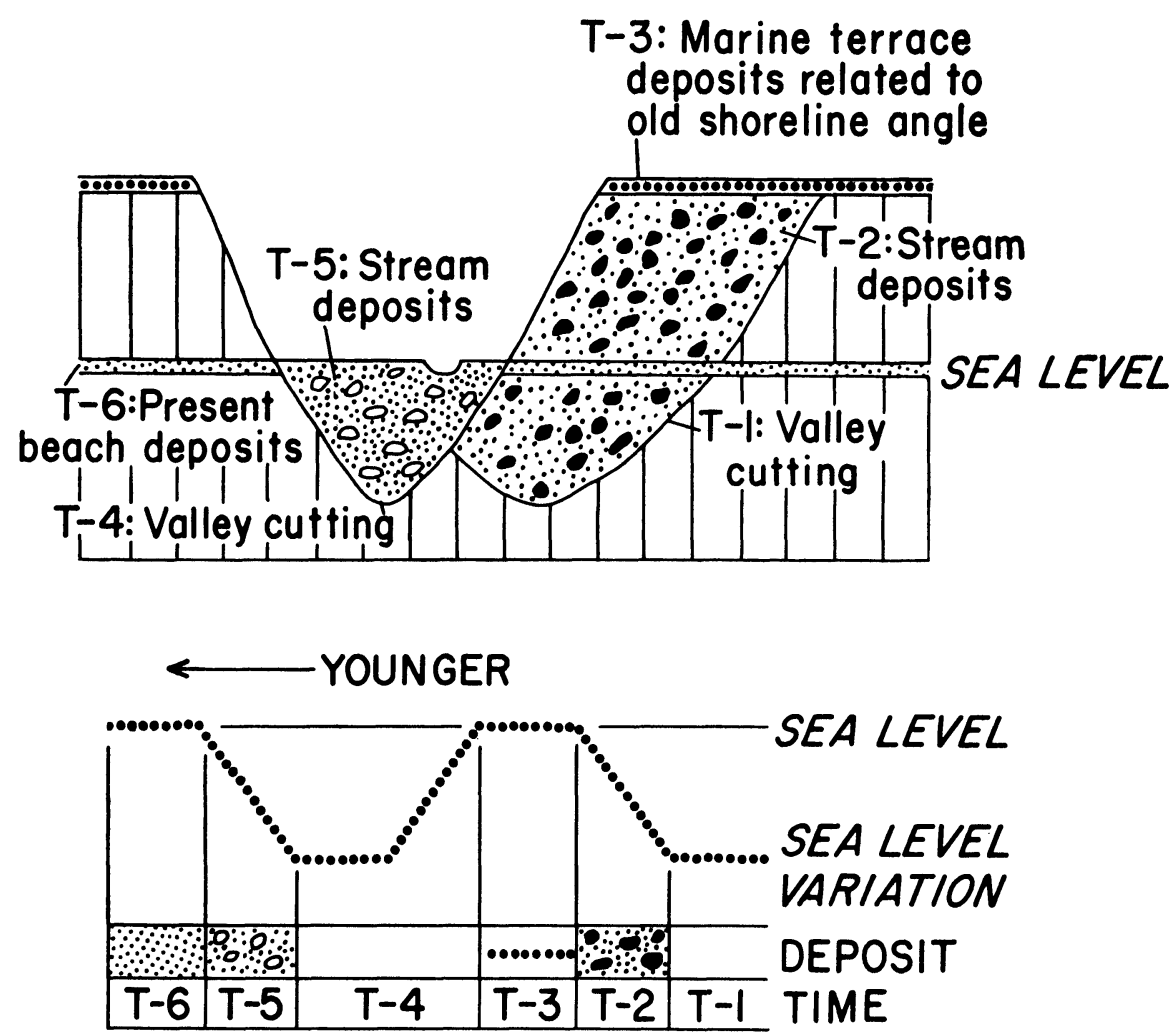

SEA LEVEL VARIATION CURVE

FIG. 7.-Schematic cross section at lower end of large stream valley showing interrelations of marine and nonmarine deposits and resulting sea-level variation curve. 
Wisconsin time and valleys were deepened (T-4, fig. 7). As glaciers melted, sea level rose to its present position $(T-6)$; this rise led to stream aggradation of the major valleys $(T-5)$. Because the Wisconsin shoreline lay seaward of the present shoreline, the altitude of the base of the Holocene stream deposits at the present shoreline is at or above the altitude of the Wisconsin shoreline. Stream-fill terrace deposits (T-2) whose top coincides with an adjacent marine shoreline angle $(T-3)$, or whose surface gradient projects downvalley to a marine shoreline angle, also indicate stream aggradation during a rising sea level. The altitude of the base of the filled valley $(T-1)$ is at or above the preceding low stand in sea level. The difference in altitude between the base of the filled valley $(T-1)$ and the marine shoreline angle that formed at the end of the transgression $(T-3)$ thus provides a minimum figure for the relative change of sea level. Major stream incision of the marine and stream deposits (T-4) is taken as evidence for a subsequent lowering of sea level. Finally, the difference in altitude between present sea level $(T-6)$ and an old shoreline angle $(T-3)$ may be partly due to coastal uplift.

Four cycles of relative sea-level variation are recognized (fig. 9). Sea level was low prior to formation of the Malibu terrace. As sea level rose to the altitude of the Malibu shoreline angle, streams aggraded and deposited 125 feet of sediment, a minimum figure for that rise in sea level. Sea level then lowered to a position at least 125 feet below the Corral shoreline angle. Sea level then rose to the Corral shoreline angle, and the transgression was recorded in one place by at least 125 feet of stream deposition. After formation of the Corral terrace, sea level lowered to at least 100 feet below the level of the Dume shoreline angle, as determined by the thickness of Dume streamfill deposits along Zuma Creek. The rise in sea level that followed resulted in aggradation of major stream valleys and formation of the Dume terrace. Sea level then lowered to at least 105 feet below its pres- ent position (some 200 feet below the Dume shoreline angle), and it subsequently has risen to its present position and has caused widespread valley aggradation.

Several processes may account for the major relative sea-level fluctuations recognized here. These include tectonic movements of continents and ocean basins, eustatic variations in sea level related to changes in glacial-ice volumes, and isostatic adjustments resulting from the loading and unloading of continental shelves by rising and falling sea level (Nansen 1921; Higgins 1965). The likelihood of late Quaternary upward tectonic movements along the Malibu coast has been discussed. Provided the direction of tectonic movement has not changed with time, regression could be due, in part, to consistent upward movement of the coast. The probable rate and magnitude of many of the regressions, however, suggest that local tectonic movements probably are not the major cause of the regressions; eustatic sea-level lowering seems a more plausible explanation. Transgressions must be the result of eustatic rise in sea level along a tectonically rising coast. Higgins (1965, 1969) and Bloom (1967) have tried to decipher the effect of isostatic adjustments caused by water loading and unloading along coasts far removed from areas formerly glaciated. As they pointed out, a coast may respond isostatically by going down during a high stand of sea level, whereas the same coast may respond by going up during a low stand of sea level. The overall history one reads from the stratigraphic record is a rise and fall in sea level that may be eustatic, but some fraction of the relative rise and fall would result from isostatic adjustment. Both Bloom (1967, p. 1490) and Higgins (1969, p. 143) suggested that isostatic adjustments may account for vertical movements of as much as one-third the average thickness of the overlying water column.

It is concluded that the major marine transgressions and regressions on the Malibu coast are mostly eustatic in origin and that this record is imprinted on a tectonical- 
ly rising coastline. Isostatic adjustments theoretically should have occurred, and they probably account for part of the relative fluctuations observed. It is not possible, however, to separate the eustatic from the isostatic component.

\section{CORRELATION WITH OTHER DATED MARINE \\ TERRACE DEPOSITS IN CALIFORNIA}

Some absolute ages that aid in correlation have been obtained for California ma- rine terrace deposits since the reviews by King (1965) and Wahrhaftig and Birman (1965). Despite the serious problems of contamination and the various ways of calculating the radiometric ages from shell material, there is a considerable amount of age agreement from widespread localities (fig. 8). For more precise correlation, however, it would be desirable to have data on eustatic sea-level variation for all dated portions of the coast.

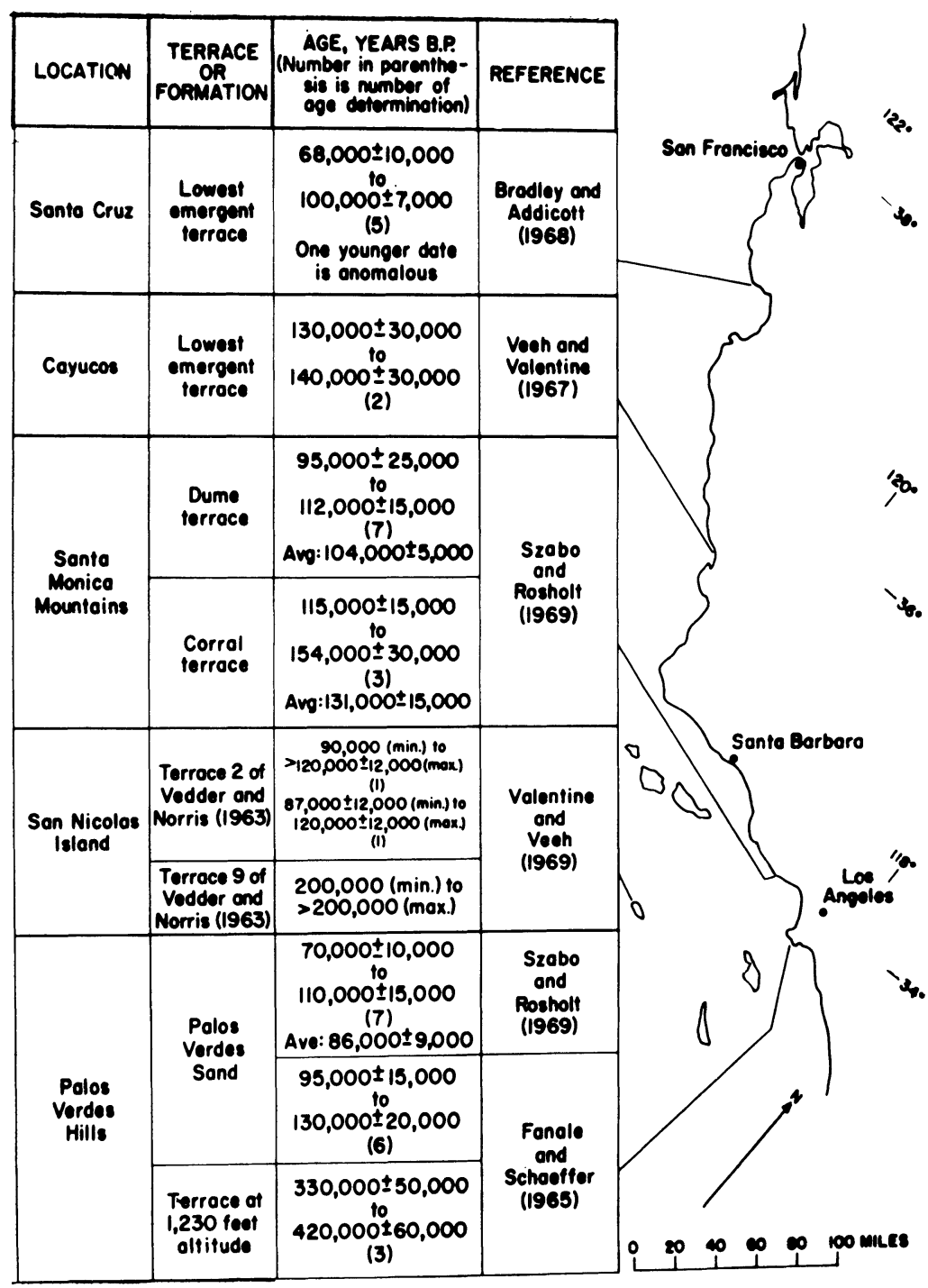

FIG. 8.--Dated marine terrace localities along the California coast 
Deposits of the lowest emergent terrace at Santa Cruz appear to have been laid down during the youngest identified preHolocene high stand of sea level (Bradley 1957, 1965). Bradley attributed at least part of the origin of the terrace to eustatic sealevel variation. Alexander (1953) worked just south of Bradley and recognized the same marine terrace. The presence of a stream-fill terrace graded to the lowest emergent marine terrace suggests formation of the latter during a eustatic high stand of sea level (Alexander 1953, p. 23). Thus, the lowest emergent terrace at Santa Cruz seems correlative with the Dume terrace on both geologic evidence and radiometric ages. Although Bradley (1965) reported progressive weathering of heavy minerals with increasing age of marine terrace deposits, this weathering was not found along the Malibu coast; hence, there is no basis for correlating the older deposits in the two areas.

Two radiometric ages for marine terrace deposits at Cayucos suggest correlation with the Corral terrace or older deposits. According to Veeh and Valentine (1967) the younger age given in figure 8 is for coral and is the more reliable of the two, although both should be considered minimum.

Terrace 2 on San Nicolas Island has a shoreline angle near 100 feet in altitude and is the lowest well-preserved marine terrace (Vedder and Norris 1963). Although no evidence is given for a possible eustatic origin for the terrace, the age determinations suggest correlation with either the Dume or the Corral terrace. Terrace 1 has a shoreline angle at about 25-30 feet in altitude, but it is not well preserved, nor has it been dated. The age of terrace 9 is only a minimum, and therefore cannot be used for correlations with the mainland.

The flight of 13 marine terraces in the Palos Verdes Hills (Woodring and others 1946) makes the area important with regard to marine terrace origin, because of the number and altitudes of the terraces. The Palos Verdes Sand lies on the lowest emergent marine terrace, and evidence for eustatic origin of the terrace was not recognized either by Woodring and others (1946) or by me during a 1-day reconnaissance study. Radiometric ages of Palos Verdes Sand determined by Szabo and Rosholt (1969) should be used for comparison with the Malibu coast, because they have dated shell material from both areas by the same methods. The Palos Verdes Sand is about the same age as the Dume terrace deposits, or slightly younger. Other low terraces in the Palos Verdes Hills have not been dated. The age of the 1,230-foothigh terrace as determined by Fanale and Schaeffer (1965) is questioned, because the method used (based on $\mathrm{He}-\mathrm{U}$ ratios) also yielded a date of $155,000 \pm 30,000$ years for the Lomita Marl. This date is not compatible with either the geologic age of the Lomita Marl (earliest Pleistocene [Woodring and others 1946]), or its K.Ar age on authigenic glauconite of 3 m.y. (Obradovich 1968).

To summarize, deposits of the lowest emergent marine terrace in several places along the California coast have somewhat similar radiometric ages. In addition, some of these deposits show evidence of deposition during the last eustatic pre-Holocene high stand of sea level. This terrace is about 100,000 years old. Deposits of the next-older eustatic high stand of sea level (Corral terrace) are more difficult to correlate. More stratigraphic- and radiometric-age data are needed to separate these two youngest high stands of sea level. Still older deposits are difficult to correlate by stratigraphic means, and some may be too old to date by the radiometric methods in use at present (Broecker 1965, p. 737-740).

\section{PROBLEM OF RECOGNIZING MID-WISCONSIN EUSTATIC HIGH STAND OF SEA LEVEL IN CALIFORNIA}

Many workers in other areas recognize one or more eustatic high stands of sea level during the Wisconsin or Würm Glaciation (Guilcher 1969, p. 85-86). Most work on this problem, for coastal areas of contermi- 
nous United States far removed from formerly ice-covered areas, has been done on the east and Gulf coasts. Estimates vary, however, on the altitude and precise age of such sea-level maxima. Curray (1965) speculated that sea level rose to slightly below its present level sometime between 22,000 and 35,000 years B.P., and Milliman and Emery (1968) believed that it was close to its present position 30,000-35,000 years B.P. In contrast, Hoyt and others (1968) inferred that sea level was slightly above its present position at about $25,000-30,000$ years B.P., and again at 40,000-48,000 years B.P. Schnable and Goodell (1968, p. $50-51,59)$ also suggested that sea level was close to its present position, or slightly above it, sometime between 24,000 and 40,000 years B.P. Osmond and others (1970) reported on a high stand of sea level dated at about 30,000 years ago. The postulated high stands of sea level generally are believed to be mid-Wisconsin in age. Mörner (1971) has questioned the existence of such high stands at that time.

Little evidence exists for a mid-Wisconsin high stand of sea level along the California coast. Marine deposits of that age have not been recognized, the only possible exception being deposits dated at $>50,000$ years B.P. in Tomales Bay, north of San Francisco (Richards and Thurber 1966). However, Alexander (1953, p. 37-38) found stream terrace deposits at altitudes below the lowest emergent marine terrace in several valleys south of Santa Cruz, and he ascribed their origin to deposition during a high stand of sea level during the Wisconsin.

Post-Dume, pre-Holocene marine deposits have not been found along the Malibu coast, suggesting that the mid-Wisconsin sea level did not rise above present sea level. That it probably was somewhat below present sea level is suggested by the present altitude of the Dume shoreline angle. Data presented here indicate that parts of the Malibu coast have been uplifted perhaps as much as 130 feet since Dume time, a rate of uplift on the order of 1-1.5 feet per 1,000 years. If we assume a uniform rate of uplift, mid-Wisconsin marine depositsif laid down at the position of present sea level-should now be some 30 feet above present sea level. The lack of such marine deposits may indicate that the mid-Wisconsin high stand of sea level was no higher than about 30 feet below present sea level. This is supported by recent data from New Guinea which suggest that the mid-Wisconsin high stand of sea level (between 35,000 and 50,000 years B.P.) could have been as much as 100 feet below present sea level (Veeh and Chappell 1970; see also fig. 9).

Some post-Dume, pre-Holocene stream deposits may be related to a mid-Wisconsin high stand of sea level. Both strath-terrace and fill-terrace deposits are present. The strath-terrace deposits could, however, have been laid down during the downcutting that accompanied the post-Dume regression. Fill-terrace deposits, however, record a change in stream regime from downcutting to aggradation, perhaps caused by a rise in base level; evidence for this is best seen at the mouth of Trancas Creek (fig. 4). There, Dume marine deposits rest on a bedrock platform both to the northwest and southeast, but on approaching the valley axis, the marine deposits and platform are trunccated by post-Dume stream-fill deposits of Trancas Creek. The stream deposits extend from below present highway level (14 feet) to an altitude above that of the marine deposits (about 40 feet); they record aggradation that is interpreted to have been continuous, inasmuch as no unconformities are recognized in the outcrop. The relations between the stream deposits and the Dume marine deposits and the inferred altitude and position of the Dume shoreline angle suggest that the fill-terrace deposits may record stream aggradation related to a midWisconsin transgression. If so, the altitude of the top of the fill-terrace deposit in the sea cliff is a maximum altitude for any midWisconsin high stand of sea level.

The suggestion of a mid-Wisconsin high stand of sea level along the California coast 

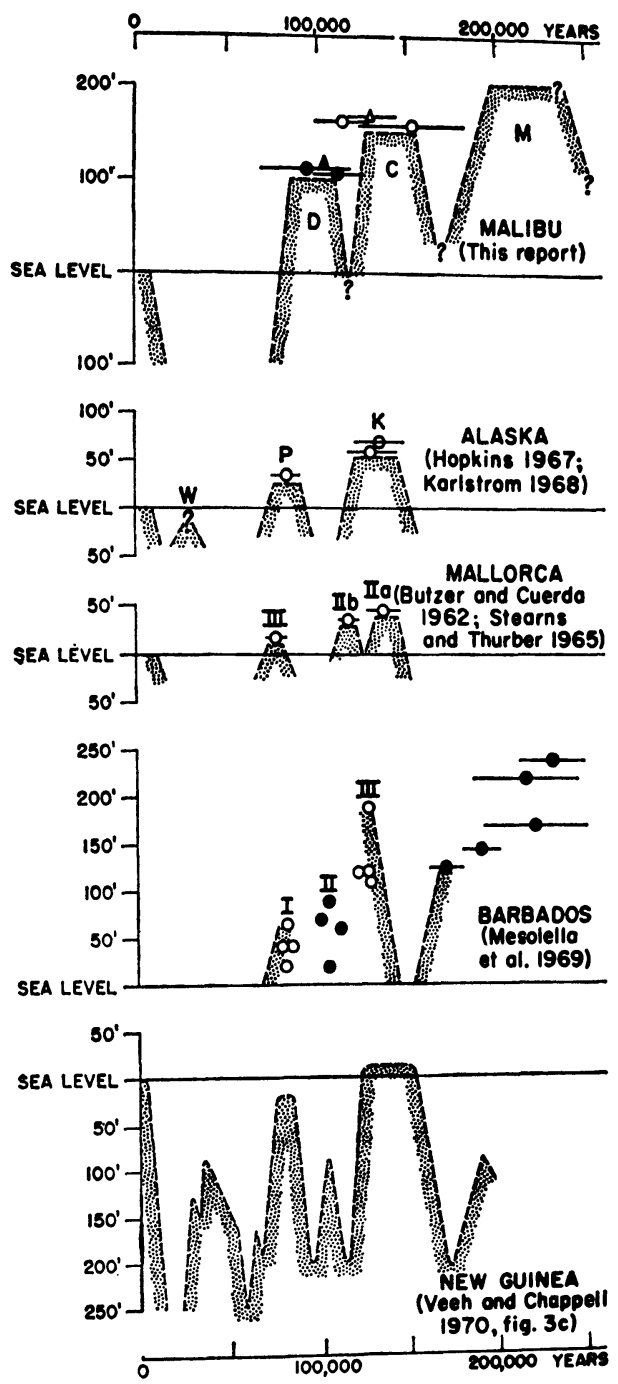

FIG. 9.-Sea-level variation curve for the Malibu coast compared with curves for several other dated coasts. Circles indicate age determinations (open for $C$ and solid for $D$ ), triangles indicate average ages, and horizontal lines show the standard error on age determinations. For the Malibu coast: $D=$ Dume, $C=$ Corral, and $M=$ Malibu; for Alaska: $W=$ Woronzofian, $P=$ Pelukian, and $K=$ Kotzebuan; for Mallorca the symbols refer to Tyrrhenian IIa, IIb, and III; and for Barbados the symbols refer to Barbados I, II, and III. At the suggestion of B. J. Szabo (personal communication, 1971), the dates for the Pelukian and Kotzebuan transgressions in Alaska are those given by Karlstrom (1968, table 2) based on a U-234/238 ratio of 1.15. Marine terrace altitude variations between the Malibu, Alaskan, Mallorcan, and Barbados coasts probably are mainly due to tectonic uplifts. For New Guinea, however, the tectonic component comes only from evidence from stream deposits. Marine deposits of that age are absent, perhaps because uplift has not been great enough to raise these deposits above present sea level. It is quite doubtful if sea level came very close to its present position then because evidence from the midcontinent suggests that a considerable amount of ice was on land during the mid-Wisconsin (Frye and others 1965; Goldthwait and others 1965).

\section{COMPARISON WITH OTHER DATED COASTLINES}

Flint (1966) has reviewed the problems of correlating Quaternary marine deposits between distant coastlines and has concluded that the best approach is to decipher relative sea-level variations from the stratigraphic record. He then used similarities in the relative sea-level curves to suggest correlation between the Virginia, Alaska, and Mallorca coasts. Since publication of his report, radiometric dates have become available for some of these and other coasts.

The similarities in relative sea-level variations between widely separated coastlines strongly suggest a common eustatic control, whereas the variation in altitudes of shoreline angles probably reflects variation in rates of uplift (fig. 9). There seem to have been two to three eustatic high stands of sea level between about 75,000 and 150,000 years B.P. This agrees with recent work of Mörner (1971). Before about 150,000 years B.P., sea level was low, and the next finite dates for a relatively high stand of sea level fall between about 170,000 and 230,000 years B.P. Deposits older than about 250,000 years B.P. are too old for the dating methods presently in use. Lack of more precise similarities between the coastlines in figure 9 may be due to some combination of tectonic and eustatic effects, preservation of stratigraphic units, and problems inherent in the various dating methods.

has been removed and the curve depicts sea-level variation relative to present sea level (radiometric age control not shown). 
ACKNowledgments.-Helpful discussions with R. H. Campbell, J. T. McGill, C. M. Wentworth, and R. F. Yerkes of the U. S. Geological Survey as well as their assistance in the fieldwork and report preparation are acknowledged. J. T. Andrews, W. C. Bradley, and K. R. Lajoie also reviewed the manuscript. R. H. Kihl conducted the particle-size distribution analyses, and S. McKee helped with the heavymineral separations. The work on which this report is based is part of a Los Angeles CountyU.S. Geological Survey cooperative program of geologic mapping of the central Santa Monica Mountains.

\section{REFERENCES CITED}

Alexandek, C. S., 1953, The marine and stream terraces of the Capitola-Watsonville area: California Univ. Pub. Geography, v. 10, no. 1, 44 p.

BLoom, A. L., 1967, Pleistocene shorelines-a new test of isostasy: Geol. Soc. America Bull., v. 78, no. 12 , p. $1477-1494$.

Bradley, W. C., 1957, Origin of marine-terrace deposits in the Santa Cruz area, California: Geol. Soc. America Bull., v. 68, no. 4, p. 421-444.

- 1965, Marine terraces on Ben Lomond Mountain, California, in Guidebook for Field Conference I, Northern Great Basin and California-Internat. Assoc. Quaternary Research 7th Cong., USA, 1965: Lincoln, Nebraska Acad. Sci., p. 148-150.

and Addicotr, W. O., 1968, Age of first marine terrace near Santa Cruz, California: Geol. Soc. America Bull., v. 79, no. 9, p. 1203-1209.

Broecker, W. S., 1965, Isotope geochemistry and the Pleistocene climatic record, in WrIGHT, $\mathrm{H}$. E., JR., and FREY, D. G., eds., The Quaternary of the United States: Princeton, N.J., Princeton Univ. Press, p. 737-753.

Butzer, K. W., and Cuerda, JuAN, 1962, Coastal stratigraphy of southern Mallorca and its implications for the Pleistocene chronology of the Mediterranean Sea: Jour. Geology, v. 70, no. 4, p. 398-416.

Campbell, R. H.; Blackerby, B. A.; Yerkes, R. F.; Schollhamer, J. E.; Birkeland, P. W.; and Wentworth, C. M., 1970, Preliminary geologic map of the Point Dume quadrangle, Los Angeles County, California: U.S. Geol. Survey Open-File Report.

- ; Yerkes, R. F.; and Wentworth, C. M., 1966, Detachment faults in the central Santa Monica Mountains, California, in Geological Survey research 1966: U.S. Geol. Survey Prof. Paper 550-C, p. C1-C11.

Curray, J. R., 1965, Late Quaternary history, continental shelves of the United States, in Wright, H. E., JR., and FrEY, D. G., eds., The Quaternary of the United States: Princeton, N.J., Princeton Univ. Press, p. 723-735.

Davis, W. M., 1933, Glacial epochs of the Santa Monica Mountains, California: Geol. Soc. American Bull., v. 44, no. 5, p. 1041-1133.

Fanale, F. P., and Schaeffer, O. A., 1965, Helium-uranium ratios for Pleistocene and Tertiary fossil aragonites: Science, v. 149, no. 3681, p. 312-317.
FLINT, R. F., 1966, Comparison of interglacial marine stratigraphy in Virginia, Alaska, and Mediterranean areas: Am. Jour. Sci. v. 264, no. 9, p. 673-684.

Frye, J. C.; Willman, H. B.; and Black, R. F., 1965, Outline of glacial geology of Illinois and Wisconsin, in WrIGHT, H. E., JR., and FrEY, D. G., eds., The Quaternary of the United States: Princeton, N.J., Princeton Univ. Press, p. 43-61. Goldthwait, R. P.; Dreimanis, Aleksis; Forsyth, J. L.; Karrow, P. F.; and White, G. W., 1965, Pleistocene deposits of the Erie Lobe, in WRIGHT, H. E., JR., and FREY, D. G., eds., The Quaternary of the United States: Princeton, N.J., Princeton Univ. Press, p. 85-97.

Guilcher, ANdré, 1969, Pleistocene and Holocene sea level changes: Earth-Sci. Rev., v. 5, no. 2, p. 68-97.

Higgins, C. G., 1965, Causes of relative sea-level changes: Am. Scientist, v. 53, no. 4, p. 464-476.

1969, Isostatic effects of sea-level changes (French Abs.), in Wright, H. E., JR., ed., Quaternary geology and climate: Internat. Assoc. Quaternary Research 7th Cong., Proc., v. 16: Natl. Acad. Sci., Pub. 1701, p. 141-145.

Hopkins, D. M., 1967, Quaternary marine transgressions in Alaska, in Hopkins, D. M., ed., The Bering land bridge: Stanford, Calif., Stanford Univ. Press, p. 47-90

Hoyt, J. H.; Henry, V. J., JR.; and Weimer, R. J., 1968, Age of Late Pleistocene shoreline deposits, coastal Georgia, in Morrison, R. B., and WRIGHT, H. E., JR., eds., Means of correlation of Quaternary successions: Internat. Assoc. Quaternary Research 7th Cong., USA, 1965, Proc., v. 8: Salt Lake City, Utah Univ. Press, p. 381-393.

KarLstrom, T. N. V., 1968, The Quaternary time scale-a current problem of correlation and radiometric dating, in MORRISON, R. B., and WRIGHT, H. E., JR., eds. Means of correlation of Quaternary successions: Internat. Assoc. Quaternary Research 7th Cong., USA, 1965, Proc., v. 8: Salt Lake City, Utah Univ. Press, p. 121-150.

KING, P. B., 1965, Tectonics of Quaternary time in Middle North America, in WrIGHT, H. E., JR., and FreY, D. G., eds., The Quaternary of the United States: Princeton, N.J., Princeton Univ. Press, p. 831-870.

Mesolella, K. J.; Matthews, R. K.; Broecker, W. S.; and Thurber, D. L., 1969, The astro- 
nomical theory of climatic change-Barbados data: Jour. Geology, v. 77, no. 3, p. 250-274.

Milliman, J. D., and EMery, K. O., 1968, Sea levels during the past 35,000 years: Science, v. 162, no. 3858 , p. $1121-1123$.

MÖRNER, NILS-AXEL, 1971, The position of the ocean level during the interstadial at about 30,000 B.P. - a discussion from a climaticgeologic point of view: Canadian Jour. Earth Sci., v. 8, no. 1, p. 132-143.

NANSEN, FridTJOF, 1921, The strandflat and isostasy: Norske Vidensk.-Akad. Oslo Skr., Mat.Naturv. Kl., v. 2, no. 11, 313 p. [1922].

Obradovich, J. D., 1968, The potential use of glauconite for late-Cenozoic geochronology, in Morrison, R. B., and Wright, H. E., JR., eds., Means of correlation of Quaternary successions: Internat. Assoc. Quaternary Research 7th Cong., USA, 1965, Proc., v. 8: Salt Lake City, Utah Univ. Press, p. 267-279.

Osmond, J. K.; May, J. P.; and Tanner, W. F., 1970, Age of the Cape Kennedy barrier-andlagoon complex: Jour. Geophys. Research, v. 75, no. 2, p. 469-479.

Powers, M. C., 1953, A new roundness scale for sedimentary particles: Jour. Sed. Petrology, v. 23, no. 2, p. 117-119.

Richards, H. G., and Thurber, D. L., 1966, Pleistocene age determinations from California and Oregon: Science, v. 152 , no. 3725 , p. 10911092.

Schnable, J. E., and Goodell, H. G., 1968, Pleistocene-Recent stratigraphy, evolution, and development of the Apalachicola coast, Florida: Geol. Soc. America Spec. Paper 112, 72 p.

Stearns, C. E., and Thurber, D. L., 1965, Th ${ }^{230}$ $\mathrm{U}^{234}$ dates of late Pleistocene marine fossils from the Mediterranean and Moroccan littorals: Quaternaria, v. 7, p. 29-42.

SzABo, B. J., and Rosholt, J. N., 1969, Uraniumseries dating of Pleistocene molluscan shells from southern California-an open system model: Jour. Geophys. Research, v. 74, no. 12, p. 32533260 .
Upson, J. E., 1949, Late Pleistocene and Recent changes of sea level along the coast of Santa Barbara County, California: Am. Jour. Sci., v. 247 , no. 2, p. 94-115.

Valentine, J. W., and Veen, H. H., 1969, Radiometric ages of Pleistocene terraces from San Nicolas Island, California: Geol. Soc. America Bull., v. 80, no. 7, p. 1415-1418.

Vedder, J. G., and NorRis, R. N., 1963, Geology of San Nicolas Island, California: U.S. Geol. Survey Prof. Paper 369, 65 p.

Veem, H. H., and Chappell, John, 1970, Astronomical theory of climatic change-support from New Guinea: Science, v. 167 , no. 3919, p. 862865 .

- and Valentine, J. W., 1967, Radiometric ages of Pleistocene fossils from Cayucos, California: Geol. Soc. America Bull., v. 78, no. 4, p. 547-550.

Wahrhaftig, Clyde, and Birman, J. H., 1965, The Quaternary of the Pacific mountain system in California, in WrIGHT, H. E., JR., and FREY, D. G., eds., The Quaternary of the United States: Princeton, N.J., Princeton Univ. Press, p. 299340.

Woodring, W. P.; Bramlette, M. N.; and Kew, W. S. W., 1946, Geology and paleontology of Palos Verdes Hills, California: U.S. Geol. Survey Prof. Paper 207, 145 p.

Yerkes, R. F.; CaMpBell, R. H.; Blackerby, B. A.; Wentworth, C. M.; Birkeland, P. W.; and Schoellhamer, J. E., 1971, Preliminary geologic map of the Malibu Beach quadrangle, Los Angeles County, California: U.S. Geol. Survey Open-File Report.

-; ; SchoellaAmer, J. E.; and WentWORTH, C. M., 1964, Preliminary geologic map and sections of the southwest part of the Topanga quadrangle, Los Angeles County, California: U.S. Geol. Survey Open-File Report.

, and Wentworth, C. M., 1965, Structure, Quaternary history, and general geology of the Corral Canyon area, Los Angeles County, California: U.S. Geol. Survey Open-File Report, 215 p. 